Adv Chronic Kidney Dis. 2008 July ; 15(3): 222-234. doi:10.1053/j.ackd.2008.04.003.

\title{
Biomarkers of Acute Kidney Injury
}

\author{
Charles L. Edelstein \\ Division of Renal Diseases, University of Colorado Health Sciences Center, Denver, CO
}

\begin{abstract}
The diagnosis of acute kidney injury (AKI) is usually based on measurements of blood urea nitrogen (BUN) and serum creatinine. BUN and serum creatinine are not very sensitive or specific for the diagnosis of AKI because they are affected by many renal and nonrenal factors that are independent of kidney injury or kidney function. Biomarkers of AKI that are made predominantly by the injured kidney have been discovered in preclinical studies. In clinical studies of patients with AKI, some of these biomarkers (eg, interleukin-18, neutrophil gelatinase-associated lipocalin, and kidney injury molecule-1) have been shown to increase in the urine before the increase in serum creatinine. These early biomarkers of AKI are being tested in different types of AKI and in larger clinical studies. Biomarkers of AKI may also predict long-term kidney outcomes and mortality.
\end{abstract}

\section{Keywords}

Biomarkers; Acute kidney injury; Interleukin-18; Neutrophil gelatinase-associated lipocalin; Kidney injury molecule-1; Cystatin C

Acute kidney injury (AKI) has been defined conceptually as a rapid decline in glomerular filtration rate (GFR) that occurs over hours or days. ${ }^{1,2}$ The recently developed RIFLE criteria (Risk of renal dysfunction, Injury to the kidney, Failure of kidney function, Loss of kidney function, and End-stage renal disease) have attempted to simplify the clinical definition and classification of AKI. ${ }^{2,3}$ The RIFLE criteria are discussed in detail in the section on "AKI: New Definitions, New Paradigms." The different definitions of AKI have hampered determination of the precise epidemiology of AKI.

AKI is common, and the absolute incidence of AKI has increased. ${ }^{4,5}$ Community-acquired AKI has been reported to account for $1 \%$ of hospital admissions in the United States. The incidence of hospital-acquired AKI is more than that of community-acquired AKI and ranges from $0.15 \%$ to $7.2 \%$ depending on the study and definition. ${ }^{5}$ In the intensive care unit (ICU), between 5\% and 20\% of critically ill patients have an episode of AKI. Up to $4.9 \%$ of critically ill patients in the ICU will require renal replacement therapy. The commonest cause of AKI in the ICU is septic shock.

Serum creatinine and blood urea nitrogen (BUN) have typically been used to diagnose AKI. Serum creatinine is dependent on nonrenal factors independent of kidney function (eg, age, sex, race, muscle mass, nutritional status, infection, and volume of distribution $\left.{ }^{6,7}\right)$. Several medications (eg, trimethoprim, cimetidine, and salicylates) alter the tubular secretion of creatinine, leading to changes in serum creatinine independent of GFR. ${ }^{6,7}$ In addition, serum

(C) 2008 by the National Kidney Foundation, Inc. All rights reserved

Address correspondence to Charles L. Edelstein, MD, Division of Renal Diseases and Hypertension, University of Colorado School of Medicine, Box C281, 4200 E 9th Avenue, Denver, CO 80262. charles.edelstein@uchsc.edu. 
creatinine is not sensitive to the loss of kidney reserve as evidenced by the small change in serum creatinine after kidney donation. ${ }^{8}$ BUN is also suboptimal for the diagnosis of AKI. BUN is dependent on nonrenal factors independent of kidney function (eg, production and renal tubular handling, protein intake, catabolic state, upper gastrointestinal bleeding, volume status, and therapy with high-dose steroids). $6,9-11$

Although the mortality in patients with AKI may have declined between 1988 and 2002,4 the mortality of AKI in the ICU remains high. ${ }^{5}$ A majority of interventional trials in AKI (eg, furosemide, ${ }^{12}$ dopamine and furosemide, ${ }^{13}$ anaratide, ${ }^{14,15}$ insulin-like growth factor- $1,{ }^{16}$ and fenoldopam ${ }^{17}$ ) have failed in humans. A possible reason for the failure of interventional trials in AKI is the dependence on serum creatinine and BUN to diagnose AKI. Alterations in serum creatinine may lag several days behind actual changes in GFR. 7,18 BUN may not be a true reflection of kidney function (eg, in patients with end-stage liver disease).

A biomarker that is released into the blood or urine by the injured kidney and is analogous to the troponin release by injured myocardial cells after myocardial ischemia, may be a more sensitive and specific marker of AKI than BUN and serum creatinine. In addition, earlier detection of AKI with a kidney specific biomarker may result in earlier nephrology consultation, more optimal dosing of antibiotics, avoidance of nephrotoxic agents and even earlier specific therapies to repair the damaged kidney. An ideal biomarker of AKI would allow the early detection of kidney injury before an increase in serum creatinine and/or BUN; would differentiate acute tubular necrosis (ATN) from acute glomerulonephritis or acute interstitial nephritis; would be able to monitor the effects of an intervention or treatment; and would predict the need for dialysis, mortality, and long-term kidney outcome.

The criteria for an ideal protein biomarker for AKI would include the following: (1) a molecule that is easy to measure in blood or urine, (2) a molecule that is stable in body fluids, and (3) a molecule that is specifically made by the kidney especially if it is produced at the site of injury (eg, the proximal tubule).

Many biomarkers have been studied in animal models of AKI and in humans and are listed in Table 1. For the purposes of the current review, the following biomarkers will be reviewed in detail: (1) interleukin-18 (IL-18); (2) neutrophil gelatinase-associated lipocalin (NGAL); (3) kidney injury molecule-1 (KIM-1); (4) tubular brush border enzymes; and (5) cystatin $\mathrm{C}$, a marker of GFR rather than of AKI.

For each biomarker, the different phases of development will be discussed: (1) preclinical studies, (2) clinical studies of validation of established disease, and (3) studies determining if the biomarker detects disease before the rise in serum creatinine.

\section{IL-18}

Caspase-1 (previously known as interleukin- $1 \beta$-converting enzyme) plays a major role in the activation of the proinflammatory cytokines IL-1 $\beta$ and IL-18. ${ }^{19}$ Caspase-1-deficient mice developed less ischemic AKI as judged by kidney function and kidney histology than wild-type mice. ${ }^{20}$ Because IL-1 $\beta$ does not play an injurious role in ischemic AKI in mice, ${ }^{21}$ a lack of the active form of IL-18 was investigated as a possible mechanism of the protection against AKI in caspase-1-deficient mice. IL-18 is involved in diverse functions including inflammation (innate immunity), ischemic tissue injury, and T-cell-mediated immunity. IL-18 plays an important role in the activation of macrophages and natural killer cells. ${ }^{22} \mathrm{IL}-18$ is a mediator of ischemic tissue injury in the heart ${ }^{23}$ and brain. ${ }^{24}$ The neutralization of IL-18 has potential therapeutic effects. Blockade of IL-18 using neutralizing antibodies, ${ }^{25}$ exogenous IL-18-binding protein (IL-18 BP), ${ }^{26}$ or caspase-1 
inhibition ${ }^{27}$ protects mice from liver necrosis. Exogenously administered recombinant human IL-18BP is therapeutically effective in a mouse model of collagen-induced arthritis. ${ }^{28} \mathrm{IL}-18 \mathrm{BP}$ reduces ischemic dysfunction in a suprafused human atrial myocardium model. ${ }^{29}$ Strategies to block IL-18 using IL-18BP are underway in clinical trials of rheumatoid arthritis. ${ }^{30}$

Thus, we determined whether caspase-1-mediated production of IL-18 played a role in ischemic AKI. In an electrochemiluminescence assay of whole kidney, IL-18 was more than $100 \%$ increased in wild-type AKI as compared with sham-operated controls. On immunoblot analysis, there was a conversion of the precursor to the active form of IL-18 in AKI wild-type mice but not in the caspase-1-deficient AKI mice and sham-operated controls. To prove that IL-18 plays an injurious role in ischemic AKI, wild-type mice were injected with rabbit antimurine IL-18 neutralizing antiserum before the ischemic insult. These mice were protected against AKI to a similar degree as caspase-1-deficient mice. The conclusion of this and other studies was that IL-18 is a mediator of ischemic AKI in mice. ${ }^{20,31}$ Immunohistochemistry of mouse kidneys showed an increase in IL-18 protein in injured tubular epithelial cells in AKI kidneys compared with normal controls. Urine IL-18 was increased in mice with ischemic AKI compared with sham-operated mice. ${ }^{20}$ Immunohistochemistry of human kidneys with AKI showed an increase of IL-18 in the tubules compared with normal control kidneys. Thus, we developed the hypothesis that IL-18 could be released from the injured tubular epithelial cells into the urine and serve as a urinary biomarker of $\mathrm{AKI}$ in humans.

Subsequent studies in humans showed that urine IL-18 is an early predictive biomarker of AKI. ${ }^{32}$ Urine IL-18 was measured in 72 patients and was significantly increased in patients with ATN versus normal controls, prerenal azotemia, urinary tract infection, chronic renal insufficiency, and nephrotic syndrome. Median urinary IL-18 concentration, measured in the first 24 hours after kidney transplantation, was higher in patients who received a cadaveric kidney that developed delayed graft function compared with patients who received a cadaveric kidney with prompt graft function and in patients who received a kidney with prompt graft function from a living donor. In the kidney-transplant patients, lower levels of urinary IL-18 were associated with a steeper decline in serum creatinine concentration over postoperative days 0 to $4 .{ }^{33}$ This study in humans showed the association of urine IL-18 with established tubular damage and formed the basis for examining urine IL-18 more extensively.

A nested case-control study within the Acute Respiratory Distress Syndrome Network Trial was performed to determine whether urinary IL-18 is an early diagnostic marker for AKI in critically ill patients in the ICU. On multivariable analysis, urine IL-18 values predicted development of AKI (defined as a 50\% increase in serum creatinine) 24 and 48 hours later. On diagnostic performance testing, urine IL-18 showed an area under the receiver-operated characteristic (ROC) curve of $73 \%$ to predict AKI in the next 24 hours. The presence of sepsis in both control and AKI patients did not have a significant effect on urinary IL-18. On multivariable analysis, the urine IL-18 value on the day of initiation of mechanical ventilation for ARDS was a strong predictor of mortality. ${ }^{34}$

AKI is a frequent complication of cardiopulmonary bypass (CPB). We tested whether IL-18 is a predictive biomarker for AKI in children after CPB. Using serum creatinine, AKI was detected only 48 to 72 hours after CPB. In contrast, urine IL-18 increased at 4 to 6 hours after CPB, peaked at over 25 -fold at 12 hours, and remained markedly elevated up to 48 hours after CPB. Our results indicate that IL-18 is an early, predictive biomarker of AKI after $\mathrm{CPB} .{ }^{35}$ On multivariate analysis, urine IL-18 was independently associated with number of days in AKI among cases, suggesting that it may be a marker of AKI severity. ${ }^{35}$ 
Delayed graft function (DGF) because of tubule cell injury frequently complicates deceased donor kidney transplants. We showed that urine NGAL and IL-18 represent early, predictive biomarkers of DGF. In patients with DGF, peak postoperative serum creatinine requiring dialysis typically occurred 2 to 4 days after transplant. Urine NGAL and IL-18 values were maximally elevated in the first 24 hours after transplant in patients with DGF. The ROC curve for prediction of DGF based on urine NGAL or IL-18 in the first 24 hours after transplant showed an area under the curve of 0.9 for both biomarkers. By multivariate analysis, both urine NGAL and IL-18 on day 0 predicted the trend in serum creatinine in the posttransplant period. ${ }^{36}$

We studied critically ill children to determine whether urinary IL-18 was an early predictor of AKI. One-hundred thirty-seven children with an average age of 6.5 years (53\% male) were studied. The peak levels of IL-18 correlated with the severity of AKI by the pediatric RIFLE (pRIFLE) classification. In nonseptic AKI patients, urinary IL-18 rose to higher levels than control levels 2 days prior than a significant rise in serum creatinine. Urinary IL-18 was associated with mortality (odds ratio $=1.29, P<.05$ ). Urinary IL-18 was increased in patients with sepsis. In conclusion, urinary IL-18 rises before serum creatinine in nonseptic critically ill children, predicts severity of AKI, and is an independent predictor of mortality. ${ }^{37}$

In summary, the proinflammatory cytokine IL-18 is both a mediator and a biomarker of ischemic AKI as evidenced by the following: (1) IL-18 expression increases in the kidney in AKI, (2) inhibition of IL-18 is protective against AKI in mice, and (3) IL-18 increases in the urine in both mice and humans with AKI.

IL-18 may be increased in other diseases besides ischemic AKI. In patients with acute kidney allograft rejection, there were higher levels of IL-18 messenger RNA in the kidney compared with patients without rejection. ${ }^{38}$ In patients with minimal-change nephrotic syndrome, urine IL-18 was significantly increased compared with control patients with immunoglobulin A nephropathy. In addition, urine IL-18 levels correlated with proteinuria and disease activity. ${ }^{39}$ In a nested case-control study of 15 patients with contrast-induced nephropathy and 36 matched controls, urinary IL-18 was measured before as well as 24 and 72 hours after cardiac catheterization. No statistically significant differences in urine IL-18 were detected between cases and controls or between the patient samples obtained before and after the cardiac catheterization. ${ }^{40}$

\section{NGAL}

NGAL is a 21-kd protein of the lipocalin superfamily. NGAL is a critical component of innate immunity to bacterial infection and is expressed by immune cells, hepatocytes, and renal tubular cells in various disease states. ${ }^{41}$ NGAL is a small secreted polypeptide that is protease resistant and thus may be easily detected in the urine.

NGAL protein increases massively in the kidney and in the first urine output in early ischemic $\mathrm{AKI}$ in rats and mice. ${ }^{42}$ The appearance of NGAL in the urine preceded the appearance of other urinary markers such as N-acetyl-beta-D-glucosaminidase and beta $2^{-}$ microglobulin. The origin of NGAL from tubule cells was confirmed in cultured human proximal tubule cells subjected to in vitro ischemic injury. NGAL was also detected in the urine of mice in the early stage of cisplatin-induced nephrotoxicity. ${ }^{43}$ These studies show that NGAL may represent an early, sensitive, noninvasive urinary biomarker for ischemic and nephrotoxic kidney injury.

Urinary and serum NGAL represent sensitive, specific, and highly predictive early biomarkers of AKI in children after cardiac surgery. ${ }^{44}$ Seventy-one children undergoing 
CPB were studied. Serial urine and blood samples were analyzed by Western blots and enzyme-linked immunosorbent assay for NGAL expression. Diagnosis of AKI, defined as a $50 \%$ increase in serum creatinine from baseline, developed 1 to 3 days after CPB. In contrast, urinary NGAL rose significantly at 2 hours after CPB. By multivariate analysis, the urinary NGAL at 2 hours after CPB was the most powerful independent predictor of AKI. In addition, 2-hour postoperative plasma NGAL levels strongly correlated with change in creatinine, duration of AKI, length of hospital stay, and mortality after CPB. ${ }^{45}$

Urinary NGAL is also an early biomarker of AKI in adults after cardiac surgery. ${ }^{46}$ Eightyone cardiac surgery patients were prospectively studied. Urine samples were collected immediately preoperatively and at various time intervals after surgery for NGAL. Mean urinary NGAL concentrations in patients who developed AKI were significantly higher early after surgery and remained significantly higher at 3 and 18 hours after cardiac surgery compared with patients who did not develop AKI.

NGAL may also represent an early sensitive biomarker of AKI after contrast administration for percutaneous coronary interven-tions (PCIs). ${ }^{47} \mathrm{NGAL}$ was measured in the serum and urine before and 2, 4, 12, 24, and 48 hours after PCI. There was a significant rise in serum NGAL 2 and 4 hours after PCI and a rise in urinary NGAL 4 and 12 hours after PCI. In multivariate analysis, serum creatinine was the only predictor of serum NGAL.

Urine NGAL is an early biomarker of AKI in critically ill children aged between 1 month and 21 years who were mechanically ventilated. ${ }^{48} \mathrm{~A}$ total of 140 patients were studied. Mean and peak urine NGAL concentrations increased with worsening pRIFLEmax status. Urine NGAL concentrations rose in AKI 2 days before and after a 50\% or greater rise in serum creatinine. Urine NGAL was a good diagnostic marker for AKI development (area under the ROC curve of 0.78 ) and persistence of AKI for 48 hours or longer (area under the ROC curve of 0.79) but not for AKI severity when it was recorded after a rise in serum creatinine had occurred (area under the ROC curve of 0.63 ).

NGAL is an early predictive biomarker of contrast-induced nephropathy (CIN) in children.

${ }^{49}$ Ninety-one children (age 0-18 years) with congenital heart disease undergoing elective cardiac catheterization and angiography with contrast administration were studied. CIN, defined as a $50 \%$ increase in serum creatinine from baseline, was found in 11 subjects $(12 \%)$. A significant elevation of NGAL concentrations in urine and plasma was noted within 2 hours after cardiac catheterization. In contrast, detection of CIN by an increase in serum creatinine was only possible 6 to 24 hours after cardiac catheterization. By multivariate analysis, the 2-hour NGAL concentrations in the urine and plasma, but not patient demographics or contrast volume, were found to be powerful independent predictors of CIN.

NGAL is also increased in other conditions besides ischemic AKI. Serum and urine NGAL levels were increased in 26 patients with autosomal dominant polycystic kidney disease, and a significant correlation was found between urine and plasma NGAL levels and residual kidney function. ${ }^{50}$ In a study of 34 children with diarrhea-associated hemolytic uremic syndrome, the majority of patients with hemolytic uremic syndrome had renal tubular epithelial injury as evidenced by elevated urinary NGAL, which was associated with higher BUN and serum creatinine concentrations, and more frequent need for dialysis. ${ }^{51}$ In a study of 85 patients, urinary NGAL, but not plasma NGAL, was found to be a biomarker of activity in lupus nephritis. ${ }^{52}$ 
KIM-1 is a putative epithelial cell adhesion molecule containing a novel immunoglobulin domain. KIM-1 messenger RNA and protein are expressed at a low level in normal kidney but are increased dramatically in postischemic kidney. ${ }^{53}$

Urinary KIM-1 is a noninvasive, rapid, sensitive, and reproducible biomarker for the early detection of both cisplatin-induced AKI and ischemic AKI in rats. ${ }^{54}$ In this study, a sandwich KIM-1 enzyme-linked immunosorbent assay test was used. At 1 day after cisplatin administration, there was a 3- to 5-fold increase in the urinary KIM-1 compared with plasma creatinine, BUN, urinary N-acetyl-beta-glucosaminidase (NAG), glycosuria, and proteinuria that were not increased in the urine. At 24 hours of postischemic reperfusion after 10 minutes of bilateral renal pedicle clamping, KIM-1 levels were 10-fold higher than control levels, and plasma creatinine and BUN, glycosuria, proteinuria, and urinary NAG levels were not yet increased. Thus, in preclinical studies, urinary NGAL and urinary KIM-1 are early biomarkers of $\mathrm{AKI}$ in mice.

KIM-1 is also a tissue and urinary biomarker for nephrotoxicant-induced kidney injury. Tissue and urinary expression were measured with 3 different nephrotoxins in the rat: S(1,1,2,2-tetrafluoroethyl)-1-cysteine, folic acid, and cisplatin. Marked increases in KIM-1 expression localized to proximal tubule epithelial cells were detected. In addition, KIM-1 protein was detected in urine of nephrotoxin-treated rats. ${ }^{55}$

KIM-1 is also a biomarker of AKI in humans. Urine samples were collected from 32 patients with various acute and chronic kidney diseases as well as from 8 normal controls. There was extensive expression of KIM-1 in proximal tubule cells in kidney biopsies from all 6 patients with biopsy-confirmed ATN. Urinary KIM-1 levels were significantly higher in patients with ischemic ATN compared with patients with other forms of acute renal failure or chronic kidney disease. Concentrations of other urinary brush border enzymes like gamma-glutamyltransferase and alkaline phosphatase did not correlate with clinical diagnostic groupings. ${ }^{56}$

KIM-1 is also a sensitive biomarker of tubular injury in other renal diseases besides AKI. Renal KIM-1 expression was significantly increased in human kidney tissue in patients with focal glomerulosclerosis, immunoglobulin A nephropathy, membranoproliferative glomerulonephritis, membranous glomerulonephritis, acute rejection, chronic allograft nephropathy, systemic lupus erythematosus, diabetic nephropathy, hypertension and Wegener's granulomatosis compared with normal kidney tissue $.^{57} \mathrm{KIM}-1$ was primarily expressed at the luminal side of dedifferentiated proximal tubules in areas with fibrosis and in areas of inflammation in macrophages. Renal KIM-1 positively correlated with kidney damage and negatively with kidney function but not with proteinuria. Urinary KIM-1 was increased in the same group of patients and correlated positively with tissue KIM-1 and macrophages and negatively with kidney function but not with proteinuria. This study shows that KIM-1 is upregulated in kidney disease and is associated with renal fibrosis and inflammation and that urinary KIM-1 can be used as a noninvasive biomarker in multiple kidney diseases.

In 25 human kidney-transplant protocol biopsies, KIM-1 staining identified proximal tubular injury and correlated with the degree of renal dysfunction. ${ }^{58}$ In the same study, it was also determined that KIM-1 expression is more sensitive than histology for detecting early tubular injury and that its level of expression may indicate the potential for recovery of kidney function. In 145 kidney-transplant recipients, urinary KIM-1 was a predictor of graft loss independent of creatinine clearance, proteinuria, and donor age ${ }^{59}$ The relationship between urinary N-acetyl-beta-(D)-glucosaminidase activity and KIM-1 level and adverse 
clinical outcomes was determined prospectively in 201 hospitalized patients with AKI. Patients with the highest levels in urinary NAG and KIM-1 had the higher odds for dialysis requirement or hospital death. This study shows that urinary biomarkers of AKI such as NAG and KIM-1 can predict adverse clinical outcomes in patients with AKI. ${ }^{60}$

\section{Tubular Enzymes}

The detection of proteins, especially enzymes, released from damaged proximal and/or distal tubular cells has also been used as a biomarker of AKI. Glutathione S-transferase isomers are cytoplasmic enzymes found in proximal and distal tubular cells. NAG is a lysosomal enzyme found mostly in proximal tubules. Alkaline phosphatase (AP), $\gamma$-glutamyl transpeptidase $(\gamma \mathrm{GT})$, and ala-(leu-gly)-aminopeptidase are brush border enzymes.

Tubular enzymuria may be very sensitive to tubular injury from multiple causes. Dipeptidyl aminopeptidase was increased in the urine in patients with tubulointerstitial nephritis and chronic glomerulonephritis. ${ }^{61}$ Of 5 brush border enzymes investigated, alkaline phosphatase was the most sensitive to detect contrast nephropathy. ${ }^{62}$ In 73 consecutive patients with nonoliguric AKI, urinary excretion of alpha ${ }_{1}$ - and beta 2 -microglobulin, cystatin $\mathrm{C}$, retinolbinding protein, alpha-glutathione $\mathrm{S}$-transferase, gamma-glutamyltransferase, lactate dehydrogenase, and N-acetyl-beta-D-glucosaminidase was measured early in the course of the AKI. ${ }^{63}$ Urinary excretion of cystatin $\mathrm{C}$ and alpha 1 -microglobulin had the highest diagnostic accuracies as indicated by the largest areas under the ROC curves in identifying patients requiring dialysis. This study concluded that, in nonoliguric AKI, increased urinary excretion of cystatin $\mathrm{C}$ and alpha ${ }_{1}$-microglobulin may predict an unfavorable outcome, as indicated by the requirement for dialysis. ${ }^{63}$ Neutral endopeptidase and retinol-binding protein were increased in the urine of patients after open heart surgery independent of kidney failure. ${ }^{64}$ It has also been shown that hemodialysis exacerbates tubular enzymuria in patients with AKI. ${ }^{65} \mathrm{AP}$, gamma-glutamyl transferase, leucine aminopeptidase, and dipeptidyl peptidase IV were measured in kidney-transplant patients with normal graft function, ATN, and acute rejection and healthy controls. Enzymuria was increased with both acute rejection and ATN. Successful treatment of rejection resulted in a decrease in the enzymuria. ${ }^{66}$ In a prospective pilot study of 26 consecutive critically ill adult patients admitted to the ICU, urinary levels of $\gamma \mathrm{GT}, \mathrm{AP}, \mathrm{NAG}$, and alpha- and pi-glutathione Stransferase (alpha- and pi-GST) but not lactate dehydrogenase were higher in the AKI group on admission and were useful in predicting AKI. ${ }^{67}$

In summary, the measurement of tubular enzymuria is inexpensive and easy to measure. However, tubular enzymuria may be increased in multiple causes of tubular injury including ATN, acute rejection, and acute tubulointerstitial nephritis.

\section{Cystatin C}

Butler and Flynn ${ }^{68}$ in 1961 studied the urine proteins of 223 individuals by starch gel electrophoresis and found a new urine protein fraction in the post $\gamma$-globulin fraction. This protein was named cystatin C. Cystatin C is a 13-kd protein produced by all nucleated cells. It is a polypeptide chain with 120 amino acid residues. It is freely filtered by the glomerulus, completely reabsorbed by the proximal tubules, and is not secreted by the renal tubules. ${ }^{69}$ Thus, some of the limitations of serum creatinine (eg, effect of muscle mass, diet, sex, and tubular secretion) may not be a problem with cystatin C. Cystatin C is best measured by an immunonephelometric assay. In studies using Cr-EDTA clearance as the reference standard, the blood concentration of this post $\gamma$-globulin fraction, known as cystatin $\mathrm{C}$, was identified as a measure of GFR. ${ }^{70}$ Cystatin $\mathrm{C}$ is a better marker of GFR than serum creatinine as shown in the following studies: serum cystatin $\mathrm{C}$ and cystatin $\mathrm{C}$ based formulae were as good in estimating GFR as the Modification of Diet in Renal Disease formula. ${ }^{71}$ Uzun et 
$\mathrm{al}^{61}$ studied the diagnostic significance of cystatin C using noncreatinine measures of GFR. Serum (99m) technetium-diethylene-triamine-penta-acetic acid (Tc-DTPA) clearance was compared with serum cystatin $\mathrm{C}$, creatinine, beta 2 -microglobulin levels and creatinine clearance in a group of patients with GFRs of 10 to $60 \mathrm{~mL} / \mathrm{min} / 1.73 \mathrm{~m}^{2}$ and healthy controls. Reference clearance, determined by serum $(99 \mathrm{~m}) \mathrm{Tc}-\mathrm{DTPA}$, was best correlated with creatinine clearance $(r=0.957)$ and cystatin $\mathrm{C}(r=.828)$ compared with beta $2^{-}$ microglobulin $(r=.767)$ and creatinine $(r=.682)$. Because these patients had a GFR of less than 60, it was concluded that serum cystatin $\mathrm{C}$ level can be used as a marker of GFR in patients with kidney failure. ${ }^{61}$ Artunc et al ${ }^{72}$ compared serum creatinine, serum cystatin $\mathrm{C}$, and the clearance of the iodinated contrast dye iopromide (reference standard) in 127 patients undergoing cardiac catheterization. Serum cystatin $\mathrm{C}$ showed a higher nonparametric correlation $(r=.805)$ to the iopromide clearance compared with creatinine $(r=$. 652) and compared with GFR estimated by the Cockcroft-Gault formula $(r=.690)$. A serum cystatin $\mathrm{C}$ value of greater than $1.3 \mathrm{mg} / \mathrm{L}$ showed an $88 \%$ sensitivity and $96 \%$ specificity for the detection of kidney failure (an iopromide clearance of less than $80 \mathrm{~mL} / \mathrm{min} / \mathrm{m}^{2}$ ). At a multinational meeting held in 2002 in Germany, ${ }^{73}$ it was decided that (1) cystatin $\mathrm{C}$ is at least equal if not superior to serum creatinine as a marker of GFR; (2) the independence from height, sex, age, and muscle mass is advantageous; (3) select patient groups such as children, the elderly, and patients with reduced muscle mass may benefit from its use as a marker of GFR.

The following studies have determined the use of cystatin $\mathrm{C}$ as a marker of low GFR in patients with kidney failure. Changes in cystatin $\mathrm{C}$ occur sooner after changes in kidney function than serum creatinine. Herget-Rosenthal studied patients after uninephrectomy for living kidney donation. Serum cystatin $\mathrm{C}$ increased 1 day after uninephrectomy compared to serum creatinine that increased at 2 days after uninephrectomy. ${ }^{8}$ Serum creatinine concentration and calculated creatinine clearance are thought to be of limited value as GFR markers in patients with decompensated liver cirrhosis. Thirty-six patients with decompensated liver cirrhosis, and 56 noncirrhotic controls were studied. Insulin clearance, serum cystatin $\mathrm{C}$, and creatinine clearances were studied. Plasma cystatin $\mathrm{C}$ concentration was found to be an accurate GFR marker in cirrhotic patients. Plasma creatinine concentration and calculated creatinine clearance were of no practical value because their reference values varied with the severity of the liver disease. ${ }^{74}$

In patients with $\mathrm{AKI}$, cystatin $\mathrm{C}$ rises before serum creatinine. In 85 patients at high risk to develop AKI, it was determined whether cystatin C detected AKI earlier than serum creatinine. AKI was defined according to the RIFLE classification. Serum cystatin C increased by more than $50 \%$ at 0.6 days earlier than the increase in serum creatinine. Serum cystatin $\mathrm{C}$ also showed a high diagnostic value to detect $\mathrm{AKI}$ as indicated by area under the ROC curve on the 2 days before the R or "risk of kidney dysfunction" criteria was fulfilled by creatinine. This study concluded that serum cystatin C is useful for the detection of AKI and may detect AKI 1 to 2 days earlier than creatinine. ${ }^{75}$ In another study in critically ill patients, serum creatinine, serum cystatin $\mathrm{C}$, and 24-hour creatinine clearance were determined. Serum cystatin C correlated better with GFR than did creatinine and was diagnostically superior to creatinine. ${ }^{76}$ During continuous veno-venous hemofiltration (CVVH), the quantity of cystatin C removed is less than $30 \%$ of its production and no rapid changes in its serum concentration are observed. ${ }^{77}$ This study suggests that CVVH is unlikely to significantly influence serum concentrations of cystatin $\mathrm{C}$ and that cystatin $\mathrm{C}$ can be used to monitor residual kidney function during $\mathrm{CVVH}$.

The reason why cystatin $\mathrm{C}$ rises before serum creatinine is not clear. A possible explanation is that cystatin $\mathrm{C}$ represents the ideal endogenous marker of GFR; it is produced by all nucleated cells at a constant rate, is not affected by changes in body mass, nutrition or sex, 
and is not degraded or secreted by the renal tubules. In contrast, serum creatinine is affected by many nonrenal factors that affect generation of creatinine and tubular secretion.

There are limitations to the use of cystatin $\mathrm{C}$ as a marker of GFR. Abnormalities of thyroid function $^{78}$ and glucocorticoid therapy ${ }^{79,80}$ may affect cystatin C independently of kidney function. Levels of C-reactive protein may increase cystatin $\mathrm{C}$ levels, suggesting that cystatin $\mathrm{C}$ is a marker of inflammation. ${ }^{81}$

Cystatin $\mathrm{C}$ is a predictor of outcome in patients with kidney failure. Cystatin $\mathrm{C}$ was a stronger predictor than serum creatinine of the risk of death and cardiovascular events in elderly persons. ${ }^{82}$ In acute non-ST-elevation myocardial infarction, cystatin C was independently associated with mortality but not with the risk of subsequent myocardial infarction. ${ }^{83}$ The association between cystatin $\mathrm{C}$ and outcome in AKI and critically ill patients remains to be determined.

\section{Panels of AKI Biomarkers}

The classical biomarker paradigm is that one test detects one disease, eg, troponin for acute myocardial infarction. However, AKI is a complex disease with multiple causes, and it is possible that one biomarker will not be sufficient to make an early diagnosis. ${ }^{84}$ Thus, a panel of biomarkers may be necessary in AKI.

Both urinary NGAL and IL-18 were measured in children who developed AKI after CPB. ${ }^{35}$ NGAL increased 25-fold within 2 hours and declined within 6 hours after surgery. In contrast, urine IL-18 increased at 4 to 6 hours after CPB, peaked at over 25 -fold at 12 hours, and remained markedly elevated up to 48 hours after CPB. Also, on multivariate analysis, both IL-18 and NGAL were independently associated with number of days in AKI among cases. These results indicate that NGAL and IL-18 are increased in tandem after CPB. The combination of these 2 biomarkers may allow for the reliable early diagnosis and prognosis of AKI at all times after CPB, much before the rise in serum creatinine. ${ }^{35} \mathrm{~A}$ panel of biomarkers of AKI may improve the early diagnosis of AKI in different populations of patients with AKI.

Urinary levels of matrix metalloproteinase-9, NAG, and KIM-1 were examined in 44 patients with various acute and chronic kidney diseases and 30 normal subjects in a crosssectional study ${ }^{85}$ In addition, a case-control study of children undergoing CPB surgery was performed. AKI was defined as a greater than $50 \%$ increase in the serum creatinine within the first 48 hours after surgery. In the cross-sectional study, combining all 3 biomarkers achieved a perfect score, as determined by the area under the ROC curve, for diagnosing AKI. In the case-control study, KIM-1 was better than NAG at all time points for early diagnosis of AKI after CPB, but combining both was no better than KIM-1 alone. Urinary matrix metalloproteinase-9 was not a sensitive marker in the case-control study. This study shows that more than 1 marker may be necessary to obtain sufficient sensitivity and specificity for AKI screening. In addition, certain biomarkers may be more useful in certain populations.

In summary, several potential urinary biomarkers exist that detect tubular injury before changes in serum creatinine. In combination, a panel of AKI biomarkers and serum markers of GFR like cystatin C may result in a greater potential to identify AKI earlier than we currently can, with resultant clinical implications. Also, clinicians that are aware of the limitations of different biomarkers in different patients may request a specific test or a panel of tests. For example, plasma cystatin $\mathrm{c}$ is a better marker of kidney failure than BUN or serum creatinine in patients with decompensated liver cirrhosis. ${ }^{74}$ Future studies should 
compare the different biomarkers of AKI and GFR in AKI due to different causes (eg, ischemia, nephrotoxins, contrast, and sepsis).

\section{Phase 4 and 5 Studies}

The TRIBE-AKI (Translational Research Investigating Biomarkers in Early Acute Kidney Injury) Clinical Consortium has been established to accelerate the development of biomarkers. The consortium is a National Institutes of Health funded multidisciplinary group and includes investigators from 7 major academic centers and who have expertise in preclinical, translational, epidemiologic, and health services research. At present, the consortium is studying the following 3 biomarkers for early diagnosis of AKI: urine IL-18, NGAL, and cystatin C. The consortium is conducting a prospective multicenter observational cohort study of 1,800 patients receiving cardiac surgery to determine whether urine IL-18, NGAL, and cystatin C are biomarkers for the early diagnosis of AKI. In addition, the hypothesis will be tested that compared with serum creatinine cystatin $\mathrm{C}$ will improve preoperative risk stratification and that urine IL-18 and NGAL levels will be better markers of postoperative AKI than serum creatinine and predict the severity of AKI and short-term mortality. The ultimate findings of this study will pave the way for larger multicenter studies of these biomarkers in other clinical conditions, for interventional clinical trials to prevent or to treat AKI, and for studies of biomarkers as predictors of longterm outcomes, like the development of chronic kidney disease and mortality, after AKI.

\section{Conclusion}

Biomarkers of AKI have been detected in preclinical studies in rats and mice. In clinical studies, some of these biomarkers have been validated in established AKI and detect AKI before the increase in serum creatinine. Prospective screening studies to determine the use of these biomarkers in larger populations are underway. Ultimately, disease-control studies to determine the impact of biomarker screening on reducing the burden of disease are desirable.

\section{Acknowledgments}

Supported by NIH grant RO1-DK-56851 (to CLE).

\section{References}

1. Lassnigg A, Schmidlin D, Mouhieddine M, et al. Minimal changes of serum creatinine predict prognosis in patients after cardiothoracic surgery: A prospective cohort study. J Am Soc Nephrol. 2004; 15:1597-1605. [PubMed: 15153571]

2. Van Biesen W, Vanholder R, Lameire N. Defining acute renal failure: RIFLE and beyond. Clin J Am Soc Nephrol. 2006; 1:1314-1319. [PubMed: 17699363]

3. Bellomo R, Kellum JA, Ronco C. Defining and classifying acute renal failure: from advocacy to consensus and validation of the RIFLE criteria. Intensive Care Med. 2007; 33:409-413. [PubMed: 17165018]

4. Waikar SS, Curhan GC, Wald R, et al. Declining mortality in patients with acute renal failure, 1988 to 2002. J Am Soc Nephrol. 2006; 17:1143-1150. [PubMed: 16495376]

5. Lameire N, Van Biesen W, Vanholder R. The changing epidemiology of acute renal failure. Nat Clin Pract Nephrol. 2006; 2:364-377. [PubMed: 16932465]

6. Stevens, LA.; Lafayette, RA.; Perrone, RD., et al. Laboratory evaluation of kidney function. In: Schrier, RW., editor. Diseases of the Kidney and Urinary Tract. 8th ed.. Lippincott, Williams and Wilkins; Philadelphia, PA: 2007.

7. Star RA. Treatment of acute renal failure. Kidney Int. 1998; 54:1817-1831. [PubMed: 9853246] 
8. Herget-Rosenthal S, Pietruck F, Volbracht L, et al. Serum cystatin C-A superior marker of rapidly reduced glomerular filtration after uninephrectomy in kidney donors compared to creatinine. Clin Nephrol. 2005; 64:41-46. [PubMed: 16047644]

9. Waikar SS, Bonventre JV. Can we rely on blood urea nitrogen as a biomarker to determine when to initiate dialysis? Clin J Am Soc Nephrol. 2006; 1:903-904. [PubMed: 17699303]

10. Walser M. Determinants of ureagenesis, with particular reference to renal failure. Kidney Int. 1980; 17:709-721. [PubMed: 6997590]

11. Luke RG. Uremia and the BUN. N Engl J Med. 1981; 305:1213-1215. [PubMed: 7290133]

12. Shilliday IR, Quinn KJ, Allison ME. Loop diuretics in the management of acute renal failure: A prospective, double-blind, placebo-controlled, randomized study. Nephrol Dial Transplant. 1997; 12:2592-2596. [PubMed: 9430857]

13. Lassnigg A, Donner E, Grubhofer G, Presterl E, et al. Lack of renoprotective effects of dopamine and furosemide during cardiac surgery. J Am Soc Nephrol. 2000; 11:97-104. [PubMed: 10616845]

14. Allgren RL, Marbury TC, Rahman SN, et al. Anaritide in acute tubular necrosis. N Engl J Med. 1997; 336:828-834. [PubMed: 9062091]

15. Lewis J, Salem MM, Chertow GM, et al. Atrial natriuretic factor in oliguric acute renal failure. Anaritide Acute Renal Failure Study Group. Am J Kidney Dis. 2000; 36:767-774. [PubMed: 11007679]

16. Hirschberg R, Kopple J, Lipsett P, et al. Multicenter clinical trial of recombinant human insulinlike growth factor I in patients with acute renal failure. Kidney Int. 1999; 55:2423-2432. [PubMed: 10354291]

17. Kellum JA. Prophylactic fenoldopam for renal protection? No, thank you, not for me-Not yet at least. Crit Care Med. 2005; 33:2681-2683. [PubMed: 16276198]

18. Moran SM, Myers BD. Course of acute renal failure studied by a model of creatinine kinetics. Kidney Int. 1985; 27:928-937. [PubMed: 4021321]

19. Dinarello CA. Biologic basis for interleukin-1 in disease. Blood. 1996; 87:2095-2147. [PubMed: 8630372]

20. Melnikov VY, Ecder T, Fantuzzi G, et al. Impaired IL-18 processing protects caspase-1-deficient mice from ischemic acute renal failure. J Clin Invest. 2001; 107:1145-1152. [PubMed: 11342578]

21. Haq M, Norman J, Saba SR, et al. Role of IL-1 in renal ischemic reperfusion injury. J Am Soc Nephrol. 1998; 9:614-619. [PubMed: 9555664]

22. Lochner M, Forster I. Anti-interleukin-18 therapy in murine models of inflammatory bowel disease. Pathobiology. 2002; 70:164-169. [PubMed: 12571421]

23. Pomerantz BJ, Reznikov LL, Harken AH, et al. Inhibition of caspase 1 reduces human myocardial ischemic dysfunction via inhibition of IL-18 and IL-1beta. Proc Natl Acad Sci U S A. 2001; 98:2871-2876. [PubMed: 11226333]

24. Hedtjarn M, Leverin AL, Eriksson K, et al. Interleukin-18 involvement in hypoxic-ischemic brain injury. J Neurosci. 2002; 22:5910-5919. [PubMed: 12122053]

25. Faggioni R, Jones-Carson J, Reed DA, et al. Leptin-deficient (ob/ob) mice are protected from $\mathrm{T}$ cell-mediated hepatotoxicity: Role of tumor necrosis factor alpha and IL-18. Proc Natl Acad Sci U S A. 2000; 97:2367-2372. [PubMed: 10681432]

26. Faggioni R, Cattley RC, Guo J, et al. IL-18-binding protein protects against lipopolysaccharideinduced lethality and prevents the development of Fas/Fas ligand-mediated models of liver disease in mice. J Immunol. 2001; 167:5913-5920. [PubMed: 11698468]

27. Fiorucci S, Santucci L, Antonelli E, et al. NO-aspirin protects from T cell-mediated liver injury by inhibiting caspase-dependent processing of Th1-like cytokines. Gastroenterology. 2000; 118:404421. [PubMed: 10648469]

28. Plater-Zyberk C, Joosten LA, Helsen MM, et al. Therapeutic effect of neutralizing endogenous IL-18 activity in the collagen-induced model of arthritis. J Clin Invest. 2001; 108:1825-1832. [PubMed: 11748266]

29. Dinarello CA. Novel targets for interleukin 18 binding protein. Ann Rheum Dis. 2001; 60(suppl 3):iii18-iii24. [PubMed: 11890646] 
30. Dinarello CA. Interleukin-18 and the treatment of rheumatoid arthritis. Rheum Dis Clin North Am. 2004; 30:417-434. [PubMed: 15172050]

31. Melnikov VY, Faubel SG, Siegmund B, et al. Neutrophil-independent mechanisms of caspase-1and IL-18-mediated ischemic acute tubular necrosis in mice. J Clin Invest. 2002; 110:1083-1091. [PubMed: 12393844]

32. Mehta RL. Urine IL-18 levels as a predictor of acute kidney injury in intensive care patients. Nat Clin Pract Nephrol. 2006; 2:252-253. [PubMed: 16932437]

33. Parikh CR, Jani A, Melnikov VY, et al. Urinary interleukin-18 is a marker of human acute tubular necrosis. Am J Kidney Dis. 2004; 43:405-414. [PubMed: 14981598]

34. Parikh CR, Abraham E, Ancukiewicz M, et al. Urine IL-18 is an early diagnostic marker for acute kidney injury and predicts mortality in the ICU. J Am Soc Nephrol. 2005; 16:3046-3052. [PubMed: 16148039]

35. Parikh CR, Mishra J, Thiessen-Philbrook H, et al. Urinary IL-18 is an early predictive biomarker of acute kidney injury after cardiac surgery. Kidney Int. 2006; 70:199-203. [PubMed: 16710348]

36. Parikh CR, Jani A, Mishra J, et al. Urine NGAL and IL-18 are predictive biomarkers for delayed graft function following kidney transplantation. Am J Transplant. 2006; 6:1639-1645. [PubMed: 16827865]

37. Washburn KK, Zapitelli M, Arikan AA, et al. Urinary interleukin-18 as an acute kidney injury biomarker in critically ill children. Nephrol Dial Transplant. 2008; 23:566-572. [PubMed: 17911094]

38. Simon T, Opelz G, Wiesel M, et al. Serial peripheral blood interleukin-18 and perforin gene expression measurements for prediction of acute kidney graft rejection. Transplantation. 2004; 77:1589-1595. [PubMed: 15239627]

39. Matsumoto K, Kanmatsuse K. Elevated interleukin-18 levels in the urine of nephrotic patients. Nephron. 2001; 88:334-339. [PubMed: 11474228]

40. Bulent Gul C, Gullulu M, Oral B, et al. Urinary IL-18: A marker of contrast-induced nephropathy following percutaneous coronary intervention. Clin Biochem. 2008; 41:544-547. [PubMed: 18237555]

41. Schmidt-Ott KM, Mori K, Li JY, et al. Dual action of neutrophil gelatinase-associated lipocalin. J Am Soc Nephrol. 2007; 18:407-413. [PubMed: 17229907]

42. Mishra J, Ma Q, Prada A, et al. Identification of neutrophil gelatinase-associated lipocalin as a novel early urinary biomarker for ischemic renal injury. J Am Soc Nephrol. 2003; 14:2534-2543. [PubMed: 14514731]

43. Mishra J, Mori K, Ma Q, et al. Neutrophil gelatinase-associated lipocalin: A novel early urinary biomarker for cisplatin nephrotoxicity. Am J Nephrol. 2004; 24:307-315. [PubMed: 15148457]

44. Mishra J, Dent C, Tarabishi R, et al. Neutrophil gelatinase-associated lipocalin (NGAL) as a biomarker for acute renal injury after cardiac surgery. Lancet. 2005; 365:1231-1238. [PubMed: 15811456]

45. Dent C, Dastrala S, Bennet M, et al. Plasma NGAL predicts AKI, morbidity and mortality after pediatric cardiac surgery: A prospective uncontrolled cohort study. Crit Care. 2007; 11:R127R132. [PubMed: 18070344]

46. Wagener G, Jan M, Kim M, et al. Association between increases in urinary neutrophil gelatinaseassociated lipocalin and acute renal dysfunction after adult cardiac surgery. Anesthesiology. 2006; 105:485-491. [PubMed: 16931980]

47. Bachorzewska-Gajewska H, Malyszko J, Sitniewska E, et al. Neutrophil-gelatinase-associated lipocalin and renal function after percutaneous coronary interventions. Am J Nephrol. 2006; 26:287-292. [PubMed: 16772710]

48. Zapitelli M, Washburn KK, Arikan AA, et al. Urine neutrophil gelatinase-associated lipocalin is an early marker of acute kidney injury in critically ill children: A prospective cohort study. Crit Care. 2007; 11:R84. [PubMed: 17678545]

49. Hirsch R, Dent C, Pfriem H, et al. NGAL is an early predictive biomarker of contrast-induced nephropathy in children. Pediatr Nephrol. 2007; 22:2089-2095. [PubMed: 17874137] 
50. Bolignano D, Coppolino G, Campo S, et al. Neutrophil gelatinase-associated lipocalin in patients with autosomal-dominant polycystic kidney disease. Am J Nephrol. 2007; 27:373-378. [PubMed: 17570904]

51. Trachtman H, Christen E, Cnaan A, et al. Investigators of the HUS-SYNSORB Pk Multicenter Clinical Trial: Urinary neutrophil gelatinase-associated lipocalcin in D+HUS: A novel marker of renal injury. Pediatr Nephrol. 2006; 21:989-994. [PubMed: 16773412]

52. Suzuki M, Wiers KM, Klein-Gitelman MS, et al. Neutrophil gelatinase-associated lipocalin as a biomarker of disease activity in lupus nephritis. Pediatr Nephrol. 2008; 23:403-412. [PubMed: 18202859]

53. Ichimura T, Bonventre JV, Bailly V, et al. Kidney injury molecule-1 (KIM-1), a putative epithelial cell adhesion molecule containing a novel immunoglobulin domain, is up-regulated in renal cells after injury. J Biol Chem. 1998; 273:4135-4142. [PubMed: 9461608]

54. Vaidya VS, Ramirez V, Ichimura T, et al. Urinary kidney injury molecule-1: A sensitive quantitative biomarker for early detection of kidney tubular injury. Am J Physiol Renal Physiol. 2006; 290:F517-F529. [PubMed: 16174863]

55. Ichimura T, Hung CC, Yang SA, et al. Kidney injury molecule-1: A tissue and urinary biomarker for nephrotoxicant-induced renal injury. Am J Physiol Renal Physiol. 2004; 286:F552-F563. [PubMed: 14600030]

56. Han WK, Bailly V, Abichandani R, et al. Kidney injury molecule-1 (KIM-1): A novel biomarker for human renal proximal tubule injury. Kidney Int. 2002; 62:237-244. [PubMed: 12081583]

57. van Timmeren MM, van den Heuvel MC, et al. Tubular kidney injury molecule-1 (KIM-1) in human renal disease. J Pathol. 2007; 212:209-217. [PubMed: 17471468]

58. Zhang PL, Rothblum LI, Han WK, et al. Kidney injury molecule-1 expression in transplant biopsies is a sensitive measure of cell injury. Kidney Int. 2008; 73:608-614. [PubMed: 18160964]

59. van Timmeren MM, Vaidya VS, van Ree RM, et al. High urinary excretion of kidney injury molecule- 1 is an independent predictor of graft loss in renal transplant recipients. Transplantation. 2007; 84:1625-1630. [PubMed: 18165774]

60. Liangos O, Perianayagam MC, Vaidya VS, et al. Urinary N-Acetyl-beta-(D)-glucosaminidase activity and kidney injury molecule-1 level are associated with adverse outcomes in acute renal failure. J Am Soc Nephrol. 2007; 18:904-912. [PubMed: 17267747]

61. Uzun H, Ozmen KM, Ataman R, et al. Serum cystatin C level as a potentially good marker for impaired kidney function. Clin Biochem. 2005; 38:792-798. [PubMed: 16005452]

62. Hartmann HG, Braedel HE, Jutzler GA. Detection of renal tubular lesions after abdominal aortography and selective renal arteriography by quantitative measurements of brush-border enzymes in the urine. Nephron. 1985; 39:95-101. [PubMed: 2858067]

63. Herget-Rosenthal S, Poppen D, Husing J, et al. Prognostic value of tubular proteinuria and enzymuria in nonoliguric acute tubular necrosis. Clin Chem. 2004; 50:552-558. [PubMed: 14709451]

64. Blaikley J, Sutton P, Walter M, et al. Tubular proteinuria and enzymuria following open heart surgery. Intensive Care Med. 2003; 29:1364-1367. [PubMed: 12856117]

65. Fink JC, Cooper MA, Zager RA. Hemodialysis exacerbates enzymuria in patients with acute renal failure: Brief report. Ren Fail. 1996; 18:947-950. [PubMed: 8948529]

66. Sarvary E, Borka P, Sulyok B, et al. Diagnostic value of urinary enzyme determination in renal transplantation. Transplant Int. 1996; 9(suppl 1):S68-S72.

67. Westhuyzen J, Endre ZH, Reece G, et al. Measurement of tubular enzymuria facilitates early detection of acute renal impairment in the intensive care unit. Nephrol Dial Transplant. 2003; 18:543-551. [PubMed: 12584277]

68. Butler FA, Flynn FV. The occurrence of post-gamma protein in urine: A new protein abnormality. J Clin Pathol. 1961; 14:172-178. [PubMed: 13689427]

69. Westhuyzen J. Cystatin C: A promising marker and predictor of impaired renal function. Ann Clin Lab Sci. 2006; 36:387-394. [PubMed: 17127725]

70. Simonsen O, Grubb A, Thysell H. The blood serum concentration of cystatin C (gamma-trace) as a measure of the glomerular filtration rate. Scand J Clin Lab Invest. 1985; 45:97-101. [PubMed: 3923607] 
71. Grubb A, Nyman U, Bjork J, et al. Simple cystatin C-based prediction equations for glomerular filtration rate compared with the modification of diet in renal disease prediction equation for adults and the Schwartz and the Counahan-Barratt prediction equations for children. Clin Chem. 2005; 51:1420-1431. [PubMed: 15961546]

72. Artunc FH, Fischer IU, Risler T, et al. Improved estimation of GFR by serum cystatin C in patients undergoing cardiac catheterization. Int J Cardiol. 2005; 102:173-178. [PubMed: 15982481]

73. Filler G, Bokenkamp A, Hofmann W, et al. Cystatin C as a marker of GFR-History, indications, and future research. Clin Biochem. 2005; 38:1-8. [PubMed: 15607309]

74. Orlando R, Mussap M, Plebani M, et al. Diagnostic value of plasma cystatin C as a glomerular filtration marker in decompensated liver cirrhosis. Clin Chem. 2002; 48:850-858. [PubMed: 12029000]

75. Herget-Rosenthal S, Marggraf G, Husing J, et al. Early detection of acute renal failure by serum cystatin C. Kidney Int. 2004; 66:1115-1122. [PubMed: 15327406]

76. Villa $\mathrm{P}$, Jimenez M, Soriano MC, et al. Serum cystatin C concentration as a marker of acute renal dysfunction in critically ill patients. Crit Care. 2005; 9:R139-R143. [PubMed: 15774046]

77. Baas MC, Bouman CS, Hoek FJ, et al. Cystatin C in critically ill patients treated with continuous venovenous hemofiltration. Hemodial Int. 2006; 10(suppl 2):S33-S37. [PubMed: 17022749]

78. Manetti L, Pardini E, Genovesi M, et al. Thyroid function differently affects serum cystatin C and creatinine concentrations. J Endocrinol Invest. 2005; 28:346-349. [PubMed: 15966508]

79. Risch L, Herklotz R, Blumberg A, et al. Effects of glucocorticoid immunosuppression on serum cystatin C concentrations in renal transplant patients. Clin Chem. 2001; 47:2055-2059. [PubMed: 11673383]

80. Risch L, Huber AR. Glucocorticoids and increased serum cystatin C concentrations. Clin Chim Acta. 2002; 320:133-134. [PubMed: 11983211]

81. Knight EL, Verhave JC, Spiegelman D, et al. Factors influencing serum cystatin C levels other than renal function and the impact on renal function measurement. Kidney Int. 2004; 65:14161421. [PubMed: 15086483]

82. Shlipak MG, Sarnak MJ, Katz R, et al. Cystatin C and the risk of death and cardiovascular events among elderly persons. N Engl J Med. 2005; 352:2049-2060. [PubMed: 15901858]

83. Jernberg T, Lindahl B, James S, et al. Cystatin C: A novel predictor of outcome in suspected or confirmed non-ST-elevation acute coronary syndrome. Circulation. 2004; 110:2342-2348. [PubMed: 15477399]

84. Herget-Rosenthal S, Bokenkamp A, Hofmann W. How to estimate GFR-serum creatinine, serum cystatin C or equations? Clin Biochem. 2007; 40:153-161. [PubMed: 17234172]

85. Han WK, Waikar SS, Johnson A, et al. Urinary biomarkers in the early diagnosis of acute kidney injury. Kidney Int. 2008; 73:863-869. [PubMed: 18059454]

86. Mori K, Lee HT, Rapoport D, et al. Endocytic delivery of lipocalin-siderophore-iron complex rescues the kidney from ischemia-reperfusion injury. J Clin Invest. 2005; 115:610-621. [PubMed: 15711640]

87. Hofmeister R, Bhargava AS, Gunzel P. Value of enzyme determinations in urine for the diagnosis of nephrotoxicity in rats. Clin Chim Acta. 1986; 160:163-167. [PubMed: 2877761]

88. Holly MK, Dear JW, Hu X, et al. Biomarker and drug-target discovery using proteomics in a new rat model of sepsis-induced acute renal failure. Kidney Int. 2006; 70:496-506. [PubMed: 16760904]

89. du Cheyron D, Daubin C, Poggioli J, et al. Urinary measurement of $\mathrm{Na}+/ \mathrm{H}+$ exchanger isoform 3 (NHE3) protein as new marker of tubule injury in critically ill patients with ARF. Am J Kidney Dis. 2003; 42:497-506. [PubMed: 12955677]

90. Muramatsu Y, Tsujie M, Kohda Y, et al. Early detection of cysteine rich protein 61 (CYR61, $\mathrm{CCN} 1)$ in urine following renal ischemic reperfusion injury. Kidney Int. 2002; 62:1601-1610. [PubMed: 12371960]

91. Fujisaki K, Kubo M, Masuda K, et al. Infusion of radiocontrast agents induces exaggerated release of urinary endothelin in patients with impaired renal function. Clin Exp Nephrol. 2003; 7:279-283. [PubMed: 14712357] 
92. Taman M, Liu Y, Tolbert E, et al. Increase urinary hepatocyte growth factor excretion in human acute renal failure. Clinical Nephrol. 1997; 48:241-245.

93. Iglesias J, Marik PE, Levine JS, et al. I: Elevated serum levels of the type I and type II receptors for tumor necrosis factor-alpha as predictive factors for ARF in patients with septic shock. Am $\mathrm{J}$ Kidney Dis. 2003; 41:62-75. [PubMed: 12500222]

94. Marcussen N, Schumann J, Campbell P, et al. Cyto-diagnostic urinalysis is very useful in the differential diagnosis of acute renal failure and can predict the severity. Ren Fail. 1995; 17:721729. [PubMed: 8771245]

95. Kwon O, Molitoris BA, Pescovitz M, et al. Urinary actin, interleukin-6, and interleukin-8 may predict sustained ARF after ischemic injury in renal allografts. Am J Kidney Dis. 2003; 41:10741087. [PubMed: 12722043]

96. Portilla D, Dent C, Sugaya T, et al. Liver fatty acid binding protein as a biomarker of acute kidney injury after cardiac surgery. Kidney Int. 2008; 73:465-472. [PubMed: 18094680] 
Table 1

Biomarkers of AKI and GFR

\begin{tabular}{|c|c|c|c|}
\hline Biomarkers of AKI & Location & Model & Reference \\
\hline \multirow[t]{3}{*}{ IL-18 } & Urine & Mice & 20 \\
\hline & & Adults & $33,34,36,40$ \\
\hline & & Children & 35 \\
\hline \multirow[t]{2}{*}{ KIM-1 } & Urine & Mice, rats, & 53,54 \\
\hline & & Humans & $56,58-60$ \\
\hline \multirow[t]{3}{*}{ NGAL } & Urine & Mice, rats & 42,86 \\
\hline & & Adults & 36 \\
\hline & & Children & $35,45,49$ \\
\hline Tubular enzymuria, eg, $\gamma \mathrm{GT}$, AP, & Urine & Rats & 87 \\
\hline NAG, glutathione S-transferase, lactate dehydrogenase & & Humans & $60,62,67$ \\
\hline Tubular enzymuria (eg, Meprin-1-alpha) & Urine & Rats & 88 \\
\hline Urine sodium/hydrogen exchanger isoform 3 (NHE3) & Urine & Humans & 89 \\
\hline Cysteine rich protein 61 (CYR61) & Urine & Rats, mice & 90 \\
\hline Low-molecular-weight proteins (eg, $\beta 2$ microglobulin, $\alpha-1$ microglobulin) & Urine & Humans & 63 \\
\hline Cystatin C & Serum & Humans & 75,76 \\
\hline Endothelin & Urine & Humans & 91 \\
\hline Hepatocyte growth factor & Urine & Humans & 92 \\
\hline Type I and II receptors for Tumor necrosis factor- $\alpha$ & Serum & Humans & 93 \\
\hline Cytodiagnostic techniques: collecting duct cells and casts & Urine & Humans & 94 \\
\hline IL-6, IL-8 & Urine & Humans (renal allografts) & 95 \\
\hline Liver fatty acid-binding protein (L-FABP) & Urine & Children & 96 \\
\hline Biomarker of GFR & Location & Model & Reference \\
\hline Cystatin C & Serum & Humans & $69-72,74$ \\
\hline
\end{tabular}

Abbreviations: AKI, acute kidney injury; GFR, glomerular filtration rate; IL, interleukin; KIM-1, kidney injury molecule-1; NGAL, neutrophil gelatinase-associated lipocalin; $\gamma \mathrm{GT}, \gamma$-glutamyl transpeptidase; AP, alkaline phosphatise; NAG, n-acetyl-glucosaminidase. 